\title{
The application of carbon nanotubes for reducing the friction losses of internal combustion engine
}

\begin{abstract}
Carbon nanotubes are a relatively new allotropic variety of carbon and due to a number of very favorable properties - including chemical and mechanical - are now under intensive investigation. Introduction to the main part of the article requires an overview of carbon nanotubes studies conducted by different authors, the results of which can provide important guidelines for possible use of the material in the construction of piston engines. The core of the article is the description of attempts to use carbon nanotubes made by the authors in order to improve the functional properties of various components of internal combustion engines, in particular to reduce losses caused by friction. Therefore, the results from the original study have been presented which indicate that the use of carbon nanotubes as an additive for engine lubricant can contribute to a significant reduction in friction losses. Article concludes with a discussion of the tasks that need to be completed in order to allow for an industrial application of carbon nanotubes.
\end{abstract}

Key words: carbon nanotubes, internal combustion engines, friction losses

\section{Zastosowanie nanorurek węglowych w celu ograniczenia strat tarcia tlokowego silnika spalinowego}

\begin{abstract}
Nanorurki weglowe stanowia niedawno poznana odmiane alotropowa wegla i ze wzgledu na wiele wyjatkowo korzystnych właściwości - między innymi chemicznych i mechanicznych - poddawane sa obecnie intensywnym badaniom. Wprowadzeniem do zasadniczej części artykulu jest przeglad takich badań nanorurek węglowych prowadzonych przez różnych autorów, których wyniki moga stanowić istotne wskazówki do zastosowania tego materiału w konstrukcji tlokowych silników spalinowych. Główna część pracy stanowi opis podjętych przez autorów tego artykułu prób wykorzystania nanorurek węglowych do poprawy właściwości funkcjonalnych różnych elementów tłokowych silników spalinowych, w szczególności w celu ograniczenia strat tarcia. W tym zakresie przedstawiono wyniki oryginalnych badań wskazujące, że zastosowanie nanorurek węglowych jako dodatku do oleju smarującego może przyczynić się do istotnego zmniejszenia strat tarcia. Artykut podsumowuja rozważania dotyczące zadań, które musza być wykonan, e aby umożliwić przemysłowe zastosowanie nanorurek weglowych.
\end{abstract}

Słowa kluczowe: nanorurki węglowe, tłokowy silnik spalinowy, straty tarcia

\section{Introduction}

Carbon nanotubes are an allotropic form of carbon, and are characterized by mechanical and chemical properties that make them extremely important when producing engines. Carbon nanotubes are a recently discovered material, and therefore were not yet used in internal combustion engines. At the same time there exists a consensus in scientific and technological circles that, given the favorable physical and chemical characteristics of carbon nanotubes, they should be much more widely used in industrial products. Industrial use of carbon nanotubes requires continuation and intensification of ongoing research. Such conclusion stems from a critical review of the state of research on implementation of carbon nanotubes into the industry, published in the journal Science $[4,32]$. Carbon nanotubes are characterized by favorable tribological properties, elasticity, vibration damping and the ability to functionalize the surface and connecting of catalyst particles, which is of great importance in the context of their application in internal combustion engines. A review of the properties of carbon nanotubes in terms of their possible use in future reciprocating internal combustion engines was made in [15].

\section{Wprowadzenie}

Nanorurki węglowe stanowią alotropową odmianę węgla i cechują się właściwościami mechanicznymi i chemicznymi, które są potencjalnie bardzo korzystne w aspekcie zastosowania w konstrukcji silników. Stanowią materiał niedawno odkryty i dlatego dotychczas nie znalazły zastosowania w silnikach. Jednocześnie w kręgach naukowych i technicznych panuje zgoda co do tego, że wobec korzystnych cech fizycznych i chemicznych nanorurek węglowych powinny one być znacznie szerzej wykorzystane w produktach przemysłowych. Zastosowanie przemysłowe nanorurek węglowych wymaga kontynuowania trwających badań $\mathrm{i}$ ich intensyfikacji. Wnioski takie wynikają między innymi z krytycznego przeglądu stanu badań wdrożeniowych nanorurek węglowych opublikowanego w czasopiśmie Science $[4,32]$. Nanorurki węglowe cechują korzystne właściwości tribologiczne, sprężystość, tłumienie drgań oraz możliwość funkcjonalizacji powierzchni i przyłączania cząstek katalizatora, co ma ogromne znaczenie w kontekście zastosowania w silniku spalinowym. Przeglądu właściwości nanorurek węglowych w aspekcie ich zastosowania w przyszłościowych tłokowych silnikach spalinowych dokonano w pracy [15]. 


\section{Carbon nanotubes as an allotropic form of carbon [15]}

Carbon may exist in amorphous form, characterized by a complete structural disorder, or create different allotropic varieties. All allotropic varieties have the same physical state, however, their physical and chemical properties differ, sometimes drasically. These differences result from the spatial arrangement of crystalline carbon atoms and their interaction. Depending on the allotropic variety carbon atoms in the crystal lattice can form $\mathrm{sp}^{2}$ or $\mathrm{sp}^{3}$ bonds. The most important, in practice, are the following allotropic varieties of carbon: graphite, graphene, diamond, fullerenes and carbon nanotubes. Figure 1 shows a schematic of the crystal lattice structure of graphite and diamond, which are best-known and most widely used allotropic varieties of carbon.

The crystal lattice of diamond is formed by $\mathrm{sp}^{3}$ bonds; each atom is bonded with four others with equal $0.154 \mathrm{~nm}$ bonds. The crystal lattice of graphite is composed of $\mathrm{sp}^{2}$ type bonds, where each atom is bonded with a length of $0.142 \mathrm{~nm}$ to three other atoms forming the same plane and having a bond of length of $0.333 \mathrm{~nm}$ with one of the atoms in an adjacent plane. Short bonds of carbon atoms that are on the same plane are much stronger than the bonds existing between adjacent planes.

Single planes isolated from the graphite structure form graphene. The existence of this alotropic variety was confirmed in 2004. Due to the extremely high strength and good electrical and thermal conductivity of graphene it is currently the subject of many studies. Ongoing attempts are being made to allow industrial use of graphene, mainly in the construction of semiconductor technology.

Carbon nanotubes are an allotropic form of carbon. The structure of their crystal lattice can be conceptually described as a plane of graphene rolled up in such a way as to set up a cylindrical peripheral surface ${ }^{1}$. As in the case of graphene, a)

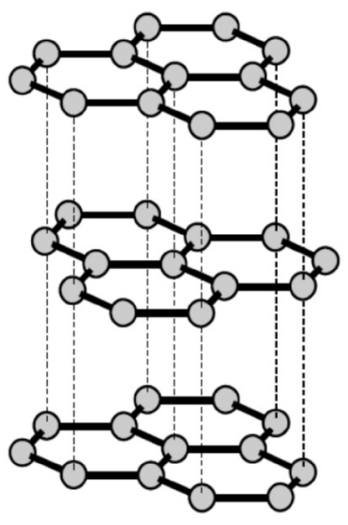

b)

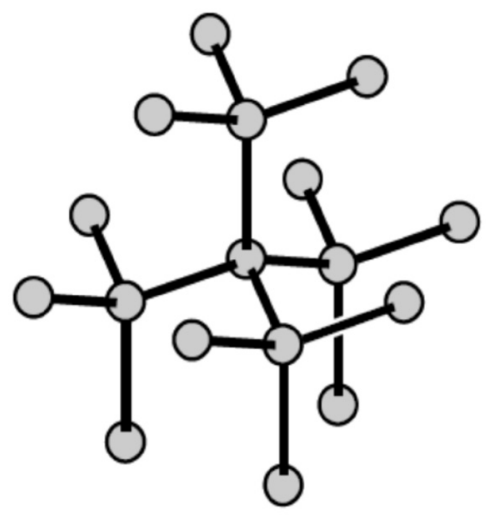

Fig. 1. Crystal structure of graphite (a) and diamond (b) Rys. 1. Struktura krystaliczna grafitu (a) i diamentu (b)

\footnotetext{
${ }^{1}$ It should be noted that the presented description is purely conceptual in character and has no relations to the synthesis process of carbon nanotubes.
}

\section{Nanorurki węglowe jako odmiana alotropowa węgla [15]}

Węgiel może występować w postaci amorficznej, cechującej się całkowitym nieuporządkowaniem atomów, lub tworzyć różne odmiany alotropowe. Wszystkie odmiany alotropowe mają ten sam stan skupienia, jednak różnią się między sobą, niekiedy diametralnie, właściwościami fizycznymi i chemicznymi. Różnice te wynikają z przestrzennej struktury krystalicznej atomów węgla i ich wzajemnego oddziaływania. W zależności od odmiany alotropowej atomy węgla w sieci krystalicznej mogą tworzyć wiązania typu $\mathrm{sp}^{2}$ lub $\mathrm{sp}^{3}$.

Największe znaczenie w praktyce mają następujące odmiany alotropowe węgla: grafit, grafen, diament, fulereny i nanorurki węglowe. Na rysunku 1 przedstawiono schematycznie strukturę sieci krystalicznej grafitu i diamentu, które są najlepiej poznanymi i najpowszechniej wykorzystywanymi odmianami alotropowymi węgla.

Sieć krystaliczna diamentu jest utworzona przez wiązania typu $\mathrm{sp}^{3}$; każdy atom łączy się $\mathrm{z}$ czterema innymi wiązaniami o jednakowej długości równej $0,154 \mathrm{~nm}$. W sieci krystalicznej grafitu występują wiązania typu sp ${ }^{2}$, przy czym każdy atom jest połączony wiązaniami o długości 0,142 nm z trzema innymi atomami tworzącymi płaszczyznę oraz wiązaniem o długości 0,333 nm z jednym z atomów w płaszczyźnie sąsiadującej. Krótkie wiązania atomów znajdujących się na jednej płaszczyźnie są znacznie silniejsze od wiązań występujących między płaszczyznami sąsiadującymi.

Pojedyncze płaszczyzny wyizolowane ze struktury grafitu tworzą grafen. Istnienie tej odmiany alotropowej zostało potwierdzone w 2004 roku. Ze względu na wyjątkowo dużą wytrzymałość oraz dobre przewodnictwo elektryczne i cieplne grafen jest obecnie przedmiotem wielu badań. Trwają próby jego zastosowania przemysłowego, głównie w technologii budowy półprzewodników.

Nanorurki węglowe to alotropowa odmiana węgla; strukturę ich sieci krystalicznej można ideowo opisać jako płaszczyznę grafenu zwiniętą w taki sposób, by utworzyła pobocznicę walca . Podobnie jak w odniesieniu do grafenu, atomy węgla tworzące nanorurkę węglową tworzą wiązania typu $\mathrm{sp}^{2}$, jednak ze względu na zakrzywienie powierzchni wiązania te mają nieco inny charakter. Pewna liczba atomów węgla w nanorurce węglowej tworzy wiązania typu $\mathrm{sp}^{3}$.

\section{Budowa i właściwości nanorurek węglowych [15]}

Wyróżnia się nanorurki jednościenne (SWCNT, single-walled carbon nanotubes) i wielościenne (MWCNT, multi-walled carbon nanotubes), zbudowane z wielu koncentrycznie złożonych nanorurek jednościennych. Na rysunku 2 przedstawiono schematycznie budowę i typowe wymiary nanorurek jednościennej i dwuścien-

\footnotetext{
Standardowe włókno węglowe nie zawiera w swej strukturze nanorurek węglowych, należy zdecydowanie odróżnić je od włókien wytwarzanych $\mathrm{z}$ nanorurek węglowych.
} 


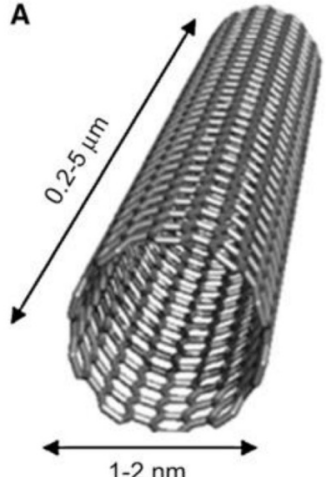

B

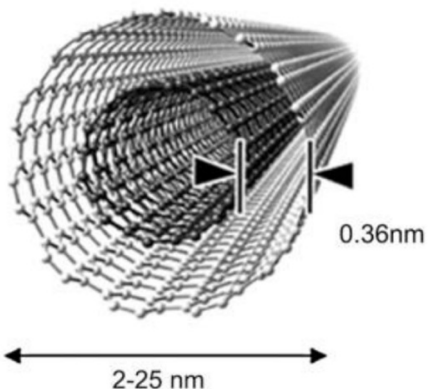

Fig. 2. Structure schematic and the typical dimensions of a singlewalled (a) and a double-walled carbon nanotube (b)

Rys. 2. Schemat budowy i typowe wymiary nanorurki weglowej jednościennej (a) i dwuściennej (b)

carbon atoms forming the carbon nanotube form $\mathrm{sp}^{2}$ bonds, but because of the curvature of the fixation surface have slightly different character a number of carbon atoms forming the carbon nanotube form $\mathrm{sp}^{3}$ type bonds.

\section{Structure and properties of carbon nanotubes [15]}

Carbon nanotubes are divided into single-walled carbon nanotubes (SWCNT) and multi-walled carbon nanotubes (MWCNT), which are made up of a number of single-

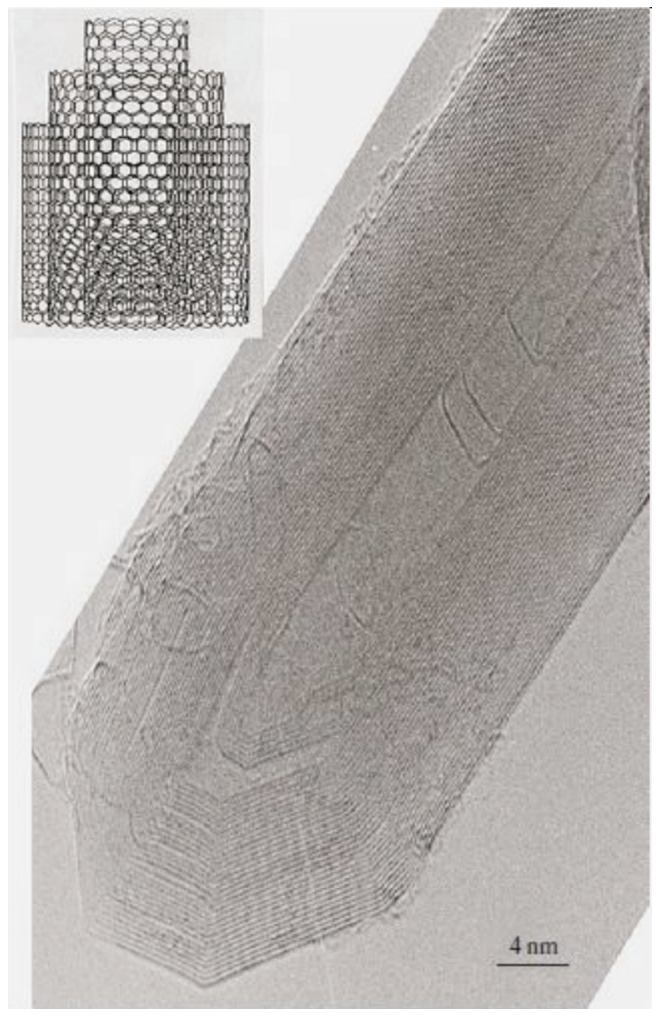

Fig. 3. Multi-walled carbon nanotube with a concentric spatial structure (c-MWNT); image obtained with TEM microscopy [5]

Rys. 3. Nanorurka wielościenna o koncentrycznej strukturze przestrzennej (c-MWNT); obraz uzyskany za pomoca mikroskopu TEM [5] nej, będącej najprostszym przykładem nanorurki wielościennej.

Średnica jednościennych nanorurek węglowych wynosi od około $0,4 \mathrm{~nm}$ do 2,5 $\mathrm{nm}$. Dolna granica wynika $\mathrm{z}$ rosnącego wraz ze zmniejszaniem promienia nanorurki poziomu energetycznego tworzonej struktury [34], górna jest związana z ograniczoną stabilnością struktury nanorurki i jej samoistnym przekształceniem do płaskiej formy o niższym poziomie energetycznym [30]. Długość nanorurek podlega jedynie ograniczeniom technicznym, wynikającym z warunków ich syntezy, i może sięgać wielu mikrometrów. Kształt nanorurek węglowych cechuje zatem niezwykle duży stosunek powierzchni do objętości, co nadaje im wiele unikalnych właściwości fizycznych i chemicznych.

Średnica zewnętrzna nanorurek wielościennych zawiera się zwykle w przedziale od kilkunastu do kilkudziesięciu nanometrów, a odległości pomiędzy kolejnymi warstwami są względnie niezmienne i wynoszą około 0,34-0,36 nm (rys. 2) $[5,6]$. Nanorurki wielościenne w najprostszej formie mogą cechować się budową koncentryczną przedstawioną na rys. 3, ale mogą też przybierać znacznie bardziej złożone formy przestrzenne, czego przykład przedstawiono na rys. 4.

Nanorurki wielościenne są wytwarzane na skalę przemysłową małym kosztem, jednak ich właściwości są na ogół gorsze w porównaniu z nanorurkami jednościennymi. Nanorurki wielościenne uzyskiwane w standardowych procesach syntezy stanowią produkt będący mieszaniną nanorurek znacznie zróżnicowanych pod względem struktury i wielkości. Przyczyną gorszych właściwości materiałowych nanorurek wielościennych jest przede wszystkim stosunkowo duża liczba defektów sieciowych, zaś rodzaj struktury przestrzennej ma znaczenie drugorzędne [5].

Ze względu na charakter niniejszej pracy w dalszej jej części omówiono dokładniej wybrane właściwości nanorurek węglowych z podziałem na:

- właściwości mechaniczne,

- właściwości chemiczne,

- przewodnictwo elektryczne i cieplne.

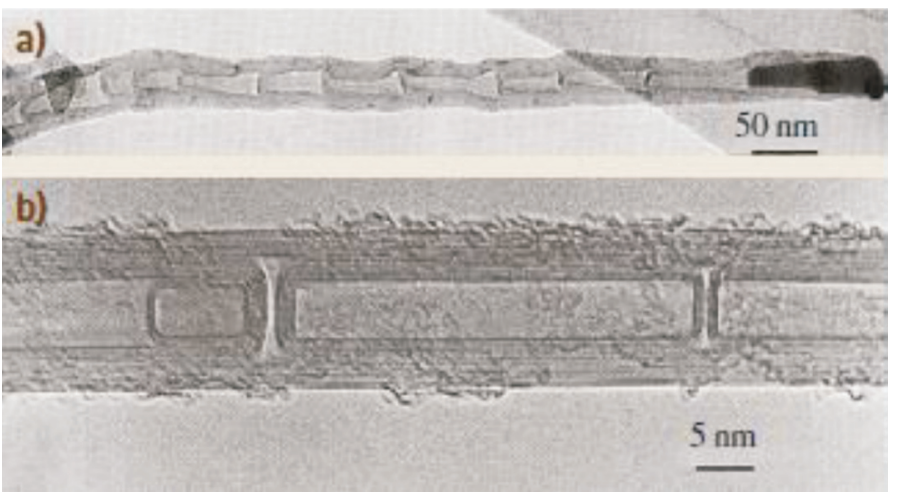

Fig. 4. Multi-walled nanotube with a bamboo-herringbone structure (bh-MWNT), the images were obtained using a TEM microscope, a) recurrence of the structure visible at low magnification; b) a close-up view of a nanotube fragment [12, 26]

Rys. 4. Nanorurka wielościenna o strukturze drzewa bambusowego (bhMWNT); obrazy uzyskane za pomoca mikroskopu TEM, a) powtarzalność struktury widoczna przy małym powiększeniu, b) fragment $w$ zbliżeniu [12, 26] 
walled nanotubes combined concentrically. Figure 2 shows the structure and typical dimensions of a single-walled and a double-walled carbon nanotube, which is the simplest example of multi-walled nanotubes.

The diameter of single-walled carbon nanotubes can vary from about $0.4 \mathrm{~nm}$ to $2.5 \mathrm{~nm}$. The lower limit results from the increase in energy level of the formed structure with the decrease of radius of the nanotubes [34], the upper limit is associated with reduced stability of the nanotube structures, and the spontaneous transformation of the nanotube to its planar form with lower energy level [30]. The length of the nanotubes is subject only to technical restrictions resulting from the conditions of their synthesis, and can reach several microns. Therefore the shape of carbon nanotubes has a very high surface to volume ratio, which gives them a number of unique physical and chemical properties.

Multi-walled nanotube outer diameter is usually in the range of several to tens of nanometers, and the distances between successive layers are relatively constant at around 0.34-0.36 nm (Fig. 2) [5, 6]. Multi-walled carbon nanotubes in their simplest form can be characterized by a concentric structure shown in Fig. 3, but can also take a much more complex spatial forms, an example of which is shown in Fig. 4.

Multi-walled nanotubes are produced on an industrial scale at relatively low cost, but their properties are generally inferior compared to the single-walled nanotubes. Multiwalled nanotubes obtained in standard synthesis processes are the product of a mixture of nanotubes that are significantly different in terms of structure and size. The cause of inferior material properties of multi-walled nanotubes is primarily a relatively large number of structural faults, while the type of the spatial structure is of lesser importance [5].

Due to the nature of this study precisely selected properties of carbon nanotubes are discussed which are divided into:

- mechanical properties

- chemical properties

- thermal and electric conductivity.

\section{Wlaściwości mechaniczne nanorurek}

Nanorurki węglowe cechują się odpornością na rozciąganie niemal o dwa rzędy większą niż odporność stali. Porównanie takie, często powtarzane w literaturze, jest nieprecyzyjne, ponieważ właściwości wytrzymałościowe pojedynczej nanorurki są zestawiane z właściwościami stali w skali makroskopowej. Dla stali dopuszczalne naprężenia zależą od struktury krystalicznej, w szczególności od obecności dyslokacji. Podobnie właściwości włókien i folii wytwarzanych z nanorurek węglowych zależą w decydującym stopniu od uporządkowania nanorurek. Obecnie wytwarzane są włókna i folie z nanorurek, które mają odporność na rozciąganie taką samą jak najlepsze gatunki stali stopowych. Uważa się, że w przyszłości będzie możliwe zwiększenie tej wartości o jeden rząd. Porównanie właściwości mechanicznych nanorurek węglowych, włókien węglowych i stali przedstawiono w tabeli 1 .

Nanorurki charakteryzują się dużą ciągliwością, ale tylko w wysokiej temperaturze. W badaniach przedstawionych w publikacji [13] uzyskano wydłużenie o 280\% i 15-krotne zmniejszenie przekroju nanorurek rozciąganych w temperaturze $2000{ }^{\circ} \mathrm{C}$ bez uszkodzenia ich struktury.

\section{Wlaściwości chemiczne nanorurek}

Nanorurki węglowe cechują się większą reaktywnością niż grafen, co wynika nie z charakteru wiązań międzyatomowych, lecz z istnienia defektów sieci utworzonej przez atomy węgla. Reaktywność chemiczna końców nanorurek jest zwykle większa niż płaskiej powierzchni bocznej; odgrywa ona szczególną rolę w wielościennych nanorurkach z otwartymi końcami (typu h-MWNT).

Jednościenne nanorurki węglowe zachowują stabilność sieci atomowej do temperatury bliskiej $2000^{\circ} \mathrm{C}$, jeżeli proces podgrzewania zachodzi w próżni lub w atmosferze gazu obojętnego. W obecności tlenu wykazano stabilność cieplną nanorurek do temperatury około $750{ }^{\circ} \mathrm{C}$, jednak procesy utleniania mogą zachodzić już w niższej temperaturze [23]. Badania odporności nanorurek węglowych na utlenianie były prowadzone przez wiele niezależnych zespołów, w atmos-

Table 1. Basic mechanical properties of carbon nanotubes, carbon fibers and steel

Tabela 1. Podstawowe właściwości nanorurek węglowych, włókien węglowych i stali

\begin{tabular}{|l|c|c|c|c|}
\hline \multicolumn{1}{|c|}{$\begin{array}{l}\text { Material/ } \\
\text { materiat }\end{array}$} & $\begin{array}{c}\text { Density/gęstość } \\
\varrho\end{array}$ & $\begin{array}{c}\text { Young's modulus/ } \\
\text { modut Younga } \\
\mathrm{E}\end{array}$ & $\begin{array}{c}\text { Tensile strength/ } \\
\text { wytrzymałość na } \\
\text { rozciaganie Rm }\end{array}$ & $\begin{array}{c}\text { Tensile strength per unit mass/ } \\
\text { wytrzymatość na rozciaganie } \\
\text { na jednostkę masy }\end{array}$ \\
\cline { 2 - 5 }$\left[\begin{array}{c}{[\mathrm{GPa}]} \\
{\left[\begin{array}{l}\text { Single-walled carbon nanotu- } \\
\text { bes/nanorurki jednościenne }\end{array}\right.}\end{array} \quad 1400\right.$ & 542 & $65(1000)^{*}$ & 462 \\
\hline $\begin{array}{l}\text { Multi-walled carbon nanotu- } \\
\text { bes/nanorurki wielościenne }\end{array}$ & 1800 & 400 & $2.7(1300)^{*}$ & 15 \\
\hline Carbon fibers/włókna węglowe & 1600 & 152 & 2.1 & 13 \\
\hline Steel/stal & 7600 & 207 & 0.7 & 1 \\
\hline *Values presented are for carbon nanotubes without structural lattice faults/wartości dla nanorurek pozbawionych defektów sieciowych [31, 35] \\
\hline
\end{tabular}

\footnotetext{
${ }^{2}$ Standard carbon fiber does not contain carbon nanotubes in its structure, it should be clearly distinguished from fibers made from carbon nanotubes.
}

${ }^{2}$ Standardowe włókno węglowe nie zawiera w swej strukturze nanorurek węglowych, należy zdecydowanie odróżnić je od włókien wytwarzanych $\mathrm{z}$ nanorurek węglowych. 


\section{Mechanical properties of carbon nanotubes}

Carbon nanotubes are characterized by a tensile strength almost two orders of magnitude greater than that of steel. Such a comparison, frequently used in literature, is imprecise because the tensile strength properties of a single nanotube is compared with the properties of steel on a macroscopic scale. In the case of steel the permissible stresses depend on the crystalline structure, in particular the presence of dislocations. Similarly, the properties of fibers and films made from carbon nanotubes are critically dependent on the arrangement of the nanotubes. Currently produced films and fibers composed of carbon nanotubes have tensile strength same as the best grades of alloy steel. It is believed that in the future it will be possible to increase that value by an order of magnitude. Comparison of mechanical properties of carbon nanotubes, carbon fibers and steel are shown in Table 1.

Carbon nanotubes have a high ductility, but only at high temperatures. The study presented in [13] obtained a $280 \%$ elongation and a 15 fold decrease in cross-sectional size of nanotubes stretched at a temperature of $2000{ }^{\circ} \mathrm{C}$ without damaging their structure.

\section{Chemical properties of carbon nanotubes}

Carbon nanotubes exhibit greater reactivity than graphene, which comes not from the nature of interatomic bonds, but the existence of defects in the lattice structure formed by carbon atoms. Chemical reactivity of the ends of the nanotubes is typically greater than the flat side surface; it plays a specific role in multi-walled nanotubes with open ends (such as h-MWNT).

Single-walled carbon nanotubes retain a stable atomic lattice in temperature up to nearly $2000{ }^{\circ} \mathrm{C}$, provided the heating process takes place in vacuum or in an inert gas atmosphere. In the presence of oxygen the thermal stability of carbon nanotubes was demonstrated to a temperature of about $750{ }^{\circ} \mathrm{C}$, although oxidation can take place at lower temperatures [23]. Tests of resistance to oxidation of carbon nanotubes have been carried out by many independent research teams, in atmospheres of different compositions. Based on these results it can be concluded that in the heating process amorphous carbon is the earliest to oxidize, then oxidation of single-walled carbon nanotubes takes place and last are the multi-walled carbon nanotubes [5].

Nanotubes are commonly used for their ability to attach different atoms onto other surfaces; which leads to the formation of covalent bonds [33]. The surface of carbon nanotubes can be subjected to functionalization involving the attachment of particles, such as platinum [6].

\section{Thermal and electric conductivity of carbon nanotubes}

Carbon nanotubes are characterized by a very good electrical conductivity. In the studies presented in [4] a current per unit cross section equal to $109 \mathrm{~A} / \mathrm{cm}^{2}$ was demonstrated, a value 1000 times greater than the maximum values obtained for conventional copper or silver. The research presented in [10] shows that the electrical conductivity of nanotubes is qualitatively different in nature than in metals. In the case ferze o zróżnicowanym składzie. Na podstawie wyników tych badań można stwierdzić, że w procesie ogrzewania najwcześniej ulega utlenieniu węgiel amorficzny, później utleniają się nanorurki jednościenne, a na końcu nanorurki wielościenne [5]. Powszechnie wykorzystuje się zdolność nanorurek do przyłączania na powierzchni różnych atomów; powstałe w ten sposób wiązania mają charakter kowalencyjny [33]. Powierzchnia nanorurek węglowych może być poddana funkcjonalizacji polegającej na przyłączeniu cząstek, na przykład platyny [6].

\section{Przewodnictwo elektryczne i cieplne nanorurek}

Nanorurki węglowe cechuje bardzo dobre przewodnictwo prądu elektrycznego. W badaniach przedstawionych w pracy [4] uzyskano natężenie prądu na jednostkę przekroju równe $109 \mathrm{~A} / \mathrm{cm}^{2}$, to jest wartość 1000 razy większą niż maksymalne wartości uzyskane dla konwencjonalnych przewodów miedzianych lub srebrnych. Z badań przedstawionych w publikacji [10] wynika, że przewodnictwo prądu elektrycznego w nanorurkach ma jakościowo inny charakter niż w metalach. W odniesieniu do nanorurek wielościennych jego wartość silnie zależy od ich struktury przestrzennej.

Unikalną cechą nanorurek węglowych jest duża wartość współczynnika przewodzenia ciepła, równa w temperaturze otoczenia $6000 \mathrm{~W} /(\mathrm{m} \cdot \mathrm{K})$, większa kilkakrotnie niż dla diamentu i ponad dziesięciokrotnie w odniesieniu do srebra. Nanorurki mają cechy anizotropowe i wykazują dobre przewodnictwo cieplne wzdłuż osi, zaś w kierunku prostopadłym są izolatorami cieplnymi [6].

\section{Pozasilnikowe badania nanorurek węglowych}

Badania wlaściwości pojedynczych nanorurek węglowych

W literaturze przedstawiono liczne prace, które polegały na wyznaczeniu współczynnika tarcia nanorurek węglowych na drodze symulacji dynamicznych procesów zachodzących w skali atomowej [21, 28, 36]. Zjawiska tarcia i adhezji w odniesieniu do pojedynczej nanorurki węglowej były również przedmiotem badań prowadzonych z zastosowaniem mikroskopowej metody wyznaczania sił AFM (atomic force microscopy) $[8,11,20]$. W obu przypadkach celem badań było wykorzystanie struktury pojedynczej nanorurki do zbudowania łożyska o gabarytach w odpowiednio małej skali. Ze względu na subatomową skalę odległości nananorurki od podłoża jej ruch uwarunkowany jest siłą tarcia oraz siłami van der Waalsa, co schematycznie przedstawiono na rys. 5. Tworzące wielościenną nanorurkę węglową atomy węgla, podlegające działaniu sił międzyatomowych, zaznaczono kolorem żółtym.

Prace prowadzone niezależnie w wielu zespołach badawczych doprowadziły do wyznaczenia współczynników tarcia różniących się o dwa rzędy wartości. Adhezja zachodząca na poziomie atomowym utrudnia ekstrapolację wyników badań prowadzonych w skali pojedynczych nanorurek na powierzchnie o wielkości makroskopowej, pozwala jednak na sprecyzowanie następujących przesłanek do badań silnikowych:

- siła tarcia nanorurek w dużym stopniu zależy od kierunku ruchu względem ich osi, 
of multi-walled nanotubes its value depends strongly on the spatial structure.

A unique feature of carbon nanotubes is a large coefficient of thermal conductivity which in the ambient temperature is equal to $6000 \mathrm{~W} /(\mathrm{m} \cdot \mathrm{K})$, several times greater than that of diamond and more than ten times that of silver. The nanotubes have anisotropic properties and exhibit good thermal conductivity along the axis while in the direction perpendicular to the axis they become thermal insulators [6].

\section{Carbon nanotube research}

\section{Testing the properties of singular carbon nanotubes}

The literature contains numerous positions, which consist of determining the friction coefficient of carbon nanotubes through the simulation of dynamic processes in atomic scale $[21,28,36]$. Friction and adhesion properties for a single carbon nanotube were also the subject of research conducted using the microscopic method of determining forces AFM (atomic force microscopy) [8, 11, 20]. In both cases, the aim of the research was to use the structure of the nanotubes to build a single bearing with suitably small dimensions. Due to the subatomic distance scale of the nanotubes to the substrate its movement is conditioned by the friction force and van der Waals forces, as schematically shown in Fig. 5. Carbon atoms forming a multi-walled carbon nanotube that were subject to interatomic forces have been marked in yellow.

The work carried out independently in several research teams led to determining the friction coefficients differing by two orders of magnitude. Adhesion occurring at the atomic level makes it difficult to extrapolate the results of research conducted in the scale of individual nanotubes to surfaces of macroscopic size, however, it allows to specify the following rationale for possible engine-related research:

- the friction force of nanotubes is largely dependent on the direction of their movement relative to their axis

- an increase in temperature increases the thermal motions of atoms which in the atomic scale leads to increased friction force

- the diameter of the carbon nanotubes does not substantially affect the value of the friction force

- the friction force increases along with the increase in speed of the nanotubes relative to the substrate

- non-carbon atoms of elements attached to the outer surface of nanotubes can greatly reduce the friction force; the use of fluorine allows for reduction of the friction coefficient to the value of $0.002-0.07$ [33].

Because of the relatively weak, resulting solely from van der Waals forces, interaction between the opposing walls of multi-walled nanotubes the carbon nanotubes can undergo deformation as shown in Fig. 5b. The deformations are elastic and reversible, and the nanotubes are not destroyed in the process due to the strong covalent bonds existing between adjacent carbon atoms. In the studies discussed in [27] single-walled and multi-walled nanotubes were subjected to normal loads, as shown in Fig. 5b. A linear relationship was found between the force and the deformation, allowing for the determination of Young's modulus. For single-walled
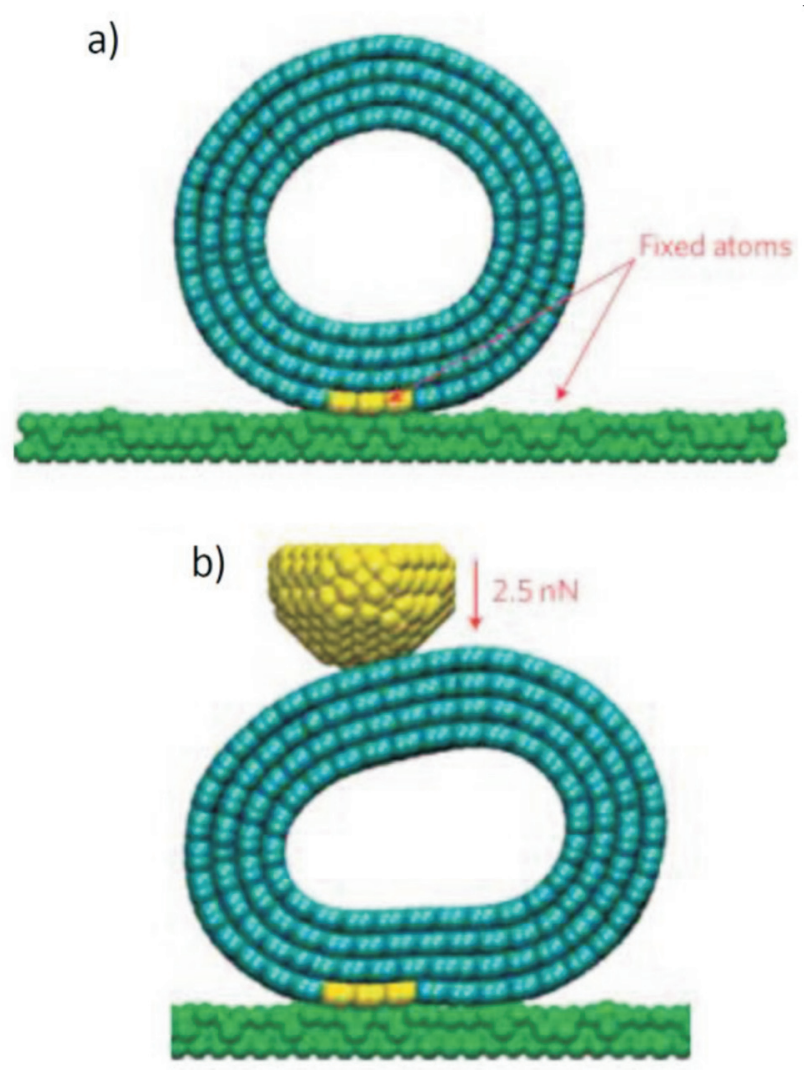

Fig. 5. Experimental determination of the friction force of a carbon nanotube; a) nanotube placed on the ground without a normal force, b) deformation of the nanotube induced by a normal force, own development based on [21]

Rys. 5. Eksperymentalne wyznaczanie sity tarcia nanorurki węglowej: a) nanorurka umieszczona na podłożu bez działania sity normalnej, b) odkształcenie nanorurki wywołane działaniem sity normalnej; opracowanie własne na podstawie [17]

- wzrost temperatury nasila ruchy cieplne atomów i w skali atomowej prowadzi do wzrostu siły tarcia,

- średnica nanorurki nie wpływa zasadniczo na wartość siły tarcia,

- siła tarcia rośnie wraz ze wzrostem prędkości nanorurki względem podłoża,

- atomy innych niż węgiel pierwiastków przyłączone do zewnętrznej powierzchni nanorurki mogą znacznie ograniczyć siłę tarcia; zastosowanie fluoru umożliwia zmniejszenie współczynnika tarcia do wartości 0,002-0,07 [33].

Ze względu na słabe, wynikające wyłącznie $z$ sił van der Waalsa, oddziaływanie między przeciwległymi ściankami nanorurki wielościenne mogą ulegać odkształceniu takiemu jak na rys. 5b. Odkształcenia mają charakter sprężysty i odwracalny, a nanorurki nie ulegają przy tym destrukcji, ponieważ między sąsiadującymi atomami węgla występują silne wiązania kowalencyjne. W badaniach omówionych w pracy [27] nanorurki jednościenne i wielościenne poddano obciążeniom normalnym, takim jak na rys. 5b. Stwierdzono liniową zależność siły i odkształcenia, co umożliwiło wyznaczenie modułu Younga. Dla nanorurek jednościennych uzyskano wartość modułu $810 \pm 410 \mathrm{GPa}$, dla wielościennych o średnicy od $26 \mathrm{~nm}$ do $76 \mathrm{~nm}$, odpowiednio, 1,28 
carbon nanotubes the value of Young's modulus of $810 \pm 410$ $\mathrm{GPa}$ was obtained, while for multi-walled nanotubes with a diameter of $26 \mathrm{~nm}$ to $76 \mathrm{~nm}$ it was $1.28 \pm 0.59 \mathrm{TPa}$. The same study found that the mechanical properties of multiwalled nanotubes obtained in the catalytic synthesis process strongly depend on their structure. The resilience of the atomic structure of carbon nanotubes can be used in the layer that covers the bearing surface of the piston for damping the forces arising from its lateral movements.

\section{The study of layers composed of carbon nanotubes}

Tribological studies of a layer of carbon nanotubes obtained by the catalytic synthesis process on the surface of silicon and cemented carbides was documented in [3]. Substrate surfaces were sprayed with nickel nanoparticles which constitute a catalyst for the synthesis of carbon nanotubes. Synthesis of carbon nanotubes has been assisted with plasma, where the selection of the parameters for the plasma has enabled adjustment of the adhesive properties of the obtained layers. Tribological tests were carried out using a ball pressed against a rotating plate placed in vacuum and in moist air. The results show the benefits of strong bonding of carbon nanotube layers with the parent material. The smallest value of the coefficient of friction of less than 0.1 was obtained for highly adhesive layers that did not undergo mechanical destruction. Furthermore, it was observed that reducing friction favors the use of layers of nanotubes with a high degree of ordering.

In an independent later project [1] carbon nanotubes have been synthesized with an ordered structure, parallel to the surface of the sample made of stainless steel. One of the experiments used an intermediate layer of cobalt, resulting in a more compact growth of nanotubes and strongly favorable tribological properties.

Although the cited research did not use engine oil or any other lubricant, the conclusions formulated on its basis may be partially applicable to the conditions of the mixed friction between the bearing surface of the piston and cylinder wall.

Due to the exceptionally favorable surface to volume ratio carbon nanotubes are often added to a variety of synthetic materials in order to improve their properties. Friction between the surfaces of carbon nanotubes suspended in a suitable resin gives coatings formed from such a composite advantageous vibration damping properties [19]. The intensity of vibration damping can be controlled by the selection of the properties of the resin and carbon nanotubes and the volume fraction of carbon nanotubes in the composite structure. The obtained results indicate that, for most applications, it is sufficient for the concentration of nanotubes to be equal to $1 \%$.

The subject of research in [29] have been the vibrationdamping properties of an epoxy resin containing carbon fibers, on the surface of which carbon nanotubes have been synthesized. Carbon nanotubes entangling carbon fibers led to a substantial increase in contact area with resin, and enabled a considerable improvement in the damping properties of the composite. The authors explain the vibration damping $\pm 0,59 \mathrm{TPa}$. W tej samej pracy stwierdzono, że właściwości mechaniczne otrzymanych w procesie syntezy katalitycznej nanorurek wielościennych silnie zależą od ich struktury. Sprężystość struktury atomowej nanorurki węglowej może być wykorzystana $\mathrm{w}$ warstwie pokrywającej powierzchnię nośną tłoka do tłumienia sił wynikających z jego ruchów poprzecznych.

\section{Badania warstw utworzonych $\mathrm{z}$ nanorurek węglowych}

Badania tribologiczne warstwy nanorurek węglowych uzyskanej w procesie katalitycznej syntezy na powierzchni krzemu i węglików spiekanych udokumentowano w literaturze [3]. Powierzchnia substratów została napylona nanocząstkami niklu, stanowiącymi katalizator w procesie syntezy nanorurek węglowych. Synteza nanorurek była wspomagana plazmą, przy czym dobór parametrów plazmy umożliwił kształtowanie właściwości adhezyjnych uzyskanych warstw. Badania tribologiczne przeprowadzono z użyciem kulki dociskanej do obracającej się płyty, w próżni i w wilgotnym powietrzu. Wyniki wskazują na korzyści wynikające z silnego związania warstw nanorurek węglowych z materiałem rodzimym. Najmniejsze wartości współczynnika tarcia, poniżej 0,1, uzyskano dla warstw o dużej adhezji, nieulegających destrukcji mechanicznej. Ponadto zaobserwowano, że do ograniczenia tarcia pożądane jest stosowanie warstw nanorurek o jak najwyższym stopniu uporządkowania.

W niezależnym, później zrealizowanym projekcie [1] dokonano syntezy nanorurek węglowych o uporządkowanej, równoległej strukturze na powierzchni próbki ze stali nierdzewnej. W jednej z wersji eksperymentu użyto pośredniej warstwy kobaltu, zyskując gęściejszy wzrost nanorurek i korzystne właściwości tribologiczne.

Chociaż w przedstawionych badaniach nie stosowano oleju ani żadnego innego smaru, sformułowane na ich podstawie wnioski mogą być w pewnym stopniu odniesione do warunków tarcia mieszanego między powierzchnią nośną tłoka i gładzią cylindra. Ze względu na wyjątkowo korzystny stosunek powierzchni do objętości nanorurki węglowe są często dodawane do różnych tworzyw sztucznych w celu poprawy ich właściwości. Tarcie między powierzchniami nanorurek zawieszonych w żywicy nadaje powłokom utworzonym z takiego kompozytu korzystne właściwości thumiące drgania [19]. Intensywność tłumienia drgań może być kształtowana między innymi przez dobór właściwości żywicy i nanorurek węglowych oraz udziału objętościowego nanorurek węglowych w strukturze kompozytu. Uzyskane wyniki badań świadczą o tym, że w większości zastosowań wystarczający jest udział nanorurek węglowych równy $1 \%$.

Przedmiotem badań prezentowanych w publikacji [29] były właściwości tłumiące drgania żywicy epoksydowej zawierającej włókna węglowe, na powierzchni których dokonano syntezy nanorurek węglowych. Nanorurki węglowe oplatające włókna węglowe przyczyniły się do znacznego zwiększenia powierzchni kontaktu z żywicą i umożliwiły znaczną poprawę właściwości tłumiących kompozytu. Tłumienie drgań i dyssypację energii autorzy tłumaczą tarciem zachodzącym między żywicą i nanorurkami. Prezentowane 
and energy dissipation effects of the substance as a result of the friction existing between the resin and the carbon nanotubes. The proposed composites [19, 29] may serve as inspiration to create layers that could be used as replacement for graphite coating used in covering the bearing surface of the piston. Similar materials are already being used in commercially produced plain bearings $[2,22,25]$.

In parallel to the resin studies described above work is underway to create carbon nanotube reinforced composites on an aluminum base. Powder metallurgy is usually used for this purpose; nanotubes are mixed with metal powder, sintered and subjected to the extrusion process [16]. This technique is time-consuming, costly and difficult to use in mass production of engine pistons. The preferred solution is to modify the surface layer of the piston material, which may consist of introducing carbon nanotubes into the parent material in the process of local melting forced by friction. A description of a successful experiment can be found in [14], which also confirmed single-walled carbon nanotubes resistance to high temperatures occurring during the executed process.

\section{The study of carbon nanotubes as an additive to lubricants}

Adding micro- and nanoparticles of substances such as copper, tungsten, molybdenum and molybdenum disulfide to the lubricating oil is a well-established method of reducing friction. Under certain conditions, friction may activate the process of deposition of these substances on the surfaces of cooperating elements, leading to the so-called friction without wearing and to reduce friction resistance [18]. Similarly, a layer of carbon nanotubes can be formed spontaneously on the friction surface by settling of nanotubes contained in the lubricating oil [7]. In study [24] single-walled carbon nanotubes were added to the lubricating oil, then a reduction in the friction forces between cooperating metal surfaces was observed. When the mass fraction of carbon nanotubes was on the level of $1 \%$ for various unit pressures the friction coefficient was found to be the lowest, equal to 0.08 . A similar test performed by a different research team obtained friction a coefficient equal to 0.087 when the mass fraction of carbon nanotubes in the oil was limited to $0.5 \%$ [9].

Based on friction force test results in subsequent work cycles [24] shown in figure $6 a$ it can be concluded that the most preferred mass fraction of carbon nanotubes is equal to $1 \%$, and a further increase in their concentration is inefficient. The change of the coefficient of friction recorded when the mass concentration of nanotubes was limited to $0.5 \%$ shows a significant reduction of frictional forces only after multiple cycles. This result indicates that the formation of a layer of nanotubes on the friction surfaces was hindered and delayed.

It is important to note that under the same operating conditions, with unit pressures equal to $0.83 \mathrm{GPa}$, carbon nanotubes dissolved in oil reduce the friction force more effectively than graphite, and C60 fullerene (Fig. 6b). Beneficial effects of modifying the friction conditions, observed in studies using friction machine, may also appear in kompozyty [19, 29] mogą stanowić inspirację do tworzenia warstw zastępujących lakier grafitowy pokrywający powierzchnię nośną tłoka. Podobne materiały są już wykorzystywane w produkowanych na skalę przemysłową łożyskach ślizgowych [2, 22, 25].

Równolegle do przedstawionych wyżej badań żywic prowadzone są prace mające na celu stworzenie wzmocnionych nanorurkami węglowymi kompozytów na osnowie aluminium. Zwykle wykorzystuje się do tego metalurgię proszków; nanorurki są mieszane z proszkiem metalu, spiekane i poddawane procesowi ekstruzji [16]. Technologia taka jest czasochłonna, kosztowna i trudna do zastosowania w wielkoseryjnej produkcji tłoków silnika. Rozwiązaniem korzystniejszym jest modyfikacja wierzchniej warstwy materiału tłoka, która może polegać na wprowadzeniu nanorurek węglowych w głąb materiału rodzimego w procesie lokalnego przetopienia wymuszonego tarciem. Opis takiego udanego eksperymentu znajduje się w artykule [14], gdzie potwierdzono jednocześnie odporność jednościennych nanorurek węglowych na wysoką temperaturę występującą chwilowo w czasie realizowanego procesu.

\section{Badania nanorurek jako dodatku do oleju smarującego}

Dodawanie do oleju smarującego mikro- i nanocząstek takich substancji, jak miedź, wolfram, molibden i dwusiarczek molibdenu jest dobrze poznaną metodą ograniczania tarcia. W pewnych warunkach tarcie może aktywować proces osadzania wymienionych substancji na powierzchniach współpracujących elementów, co prowadzi do tzw. tarcia bezzużyciowego i do zmniejszenia oporów tarcia [18]. Podobnie warstwa nanorurek węglowych na powierzchni trącej może się utworzyć samoistnie, przez osiadanie nanorurek zawartych w oleju smarującym [7]. W badaniach prezentowanych w pracy [24] do oleju smarującego dodano jednościenne nanorurki węglowe i zaobserwowano zmniejszenie siły tarcia współpracujących powierzchni metalowych. Przy udziale masowym nanorurek węglowych na poziomie 1\% w zakresie różnych nacisków jednostkowych uzyskano najmniejszą wartość współczynnika tarcia, równą 0,08 . W wyniku podobnych badań przeprowadzonych w niezależnym zespole otrzymano wartość współczynnika tarcia równą 0,087 przy udziale masowym nanorurek węglowych w oleju ograniczonym do $0,5 \%$ [9].

Na podstawie przedstawionych na rys. 6a wyników badań siły tarcia w kolejnych cyklach pracy [24] można wnioskować, że najkorzystniejszy jest udział masowy nanorurek równy $1 \%$, a dalsze zwiększanie ich koncentracji jest nieefektywne. Jednocześnie przebieg współczynnika tarcia zarejestrowany dla stężenia masowego nanorurek ograniczonego do $0,5 \%$ przedstawia znaczne zmniejszenie siły tarcia występujące dopiero po wielu cyklach. Taki wynik wskazuje na utrudnione i opóźnione tworzenie warstwy nanorurek na powierzchniach trących.

Jest znamienne, że w tych samych warunkach pracy, przy naciskach jednostkowych równych $0,83 \mathrm{GPa}$, nanorurki węglowe rozpuszczone w oleju skuteczniej ograniczają siłę tarcia niż grafit i fuleren C60 (rys. 6b). Korzystne efekty 
a combustion engine, specifically in the nodes where there is mixed friction.

The concept of adding carbon nanotubes or other nanoparticles of molybdenum disulfide to the lubricating oil is a separate issue [17].

\section{Using carbon nanotubes as an additive to engine lubricants used in a piston engine}

\section{Research concept}

The study was conducted on a VW TDI type AXD engine. It is a 5 cylinder turbocharged diesel engine with an engine displacement of approximately $2.5 \mathrm{dm}^{3}$ and a maximum power of $96 \mathrm{~kW}$. The investigation of the effect of carbon nanotubes additive for motor oil involved comparing the external drive torque of an engine lubricated with a reference motor oil; Shell Formula SAE 10W-30, API SN, ILSAC GF-5 and the corresponding results obtained for an engine which used the same oil with the addition of multi-walled carbon nanotubes with a mass concentration of about $1 \%$. To ensure the reproducibility of test results the following measures were taken:

- In each case, the oil level was set for a cold engine to reach the minimum amount plus $2 / 3$ of the height between the recommended minimum and maximum levels on the oil dipstick.

- In order to avoid distortions due to the additional load on the engine by the crankshaft driven alternator the same battery was fully charged using an external source before each measurement. For the same purpose the electrical circuit powering the spark plugs has been disconnected.

- All tests for both types of oil, were carried out on the engine with the oil filter disassembled. Filter was dismantled in order to avoid formation of agglomerates of carbon nanotubes in the oil filter.

- Before each test the torque measuring system had been left working for approximately 2 hours, and only after that time the measuring system was reset.

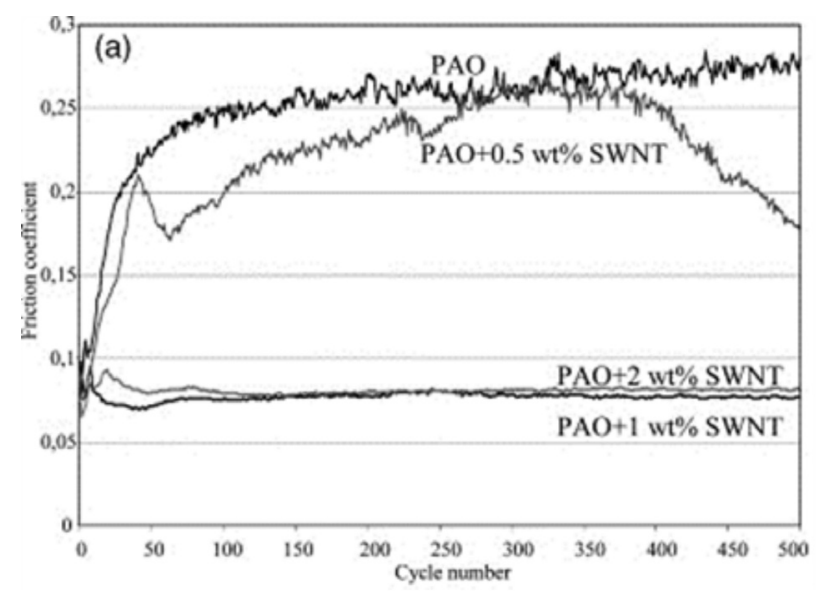

modyfikacji warunków tarcia obserwowane w badaniach prowadzonych z wykorzystaniem maszyny tarciowej mogą się ujawnić również w silniku spalinowym, w tych jego węzłach, gdzie występuje tarcie mieszane.

Odrębne zagadnienie stanowi koncepcja dodawania do oleju smarującego nanorurek lub innych nanocząstek dwusiarczku molibdenu [17].

\section{Badania nanorurek węglowych jako dodatku do oleju smarującego zastosowanego w tlokowym silniku spalinowym}

\section{Koncepcja badań}

Badania przeprowadzono na silniku VW TDI, typu AXD - jest to pięciocylindrowy, doładowany turbosprężarką silnik ZS o objętości skokowej około $2,5 \mathrm{dm}^{3}$ i maksymalnej mocy $96 \mathrm{~kW}$. Badania wpływu dodatku nanorurek węglowych do oleju silnikowego polegały na porównaniu momentu napędu zewnętrznego silnika smarowanego olejem referencyjnym Formula Shell SAE 10W-30, API SN, ILSAC GF-5 z odpowiednimi wynikami uzyskanymi dla silnika, w którym znajdował się taki sam olej z dodatkiem wielościennych nanorurek węglowych o stężeniu masowym równym około $1 \%$. Aby zapewnić powtarzalność badań podjęto między innymi następujące działania:

- W każdym przypadku poziom oleju ustalony w zimnym silniku na bagnecie kontrolnym sięgał wskaźnika minimum plus $2 / 3$ wysokości pomiędzy zalecanym poziomem minimalnym i maksymalnym.

- W celu wyeliminowania zakłóceń wynikających z dodatkowego obciążenia silnika przez napędzany od wału korbowego alternator przed każdym pomiarem ten sam akumulator był całkowicie naładowany z wykorzystaniem źródła zewnętrznego. W tym samym celu rozłączono obwód elektryczny świec żarowych.

- Wszystkie badania, dla obu rodzajów oleju, przeprowadzono na silniku ze zdemontowanym filtrem oleju. Filtr

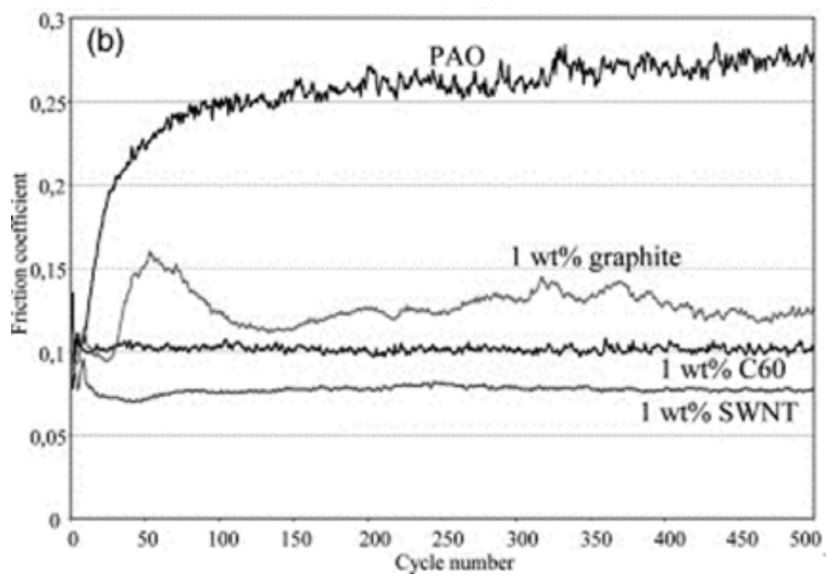

Fig. 6. Changes in the friction coefficient of two metallic surfaces in subsequent cycles; results of additives dissolved in the lubricating oil; a) an oil containing nanotubes of different mass concentration, b) oil containing carbon nanotubes and other varieties of allotropic atoms [24]

Rys. 6. Zmiany wspótczynnika tarcia dwóch powierzchni metalowych w kolejnych cyklach pracy; wyniki badań dodatków rozpuszczonych w oleju smarujacym: a) olej z dodatkiem nanorurek o zróżnicowanym stężeniu masowym, b) olej z dodatkiem nanorurek $i$ innych odmian alotropowych węgla; opracowanie własne na podstawie [24] 


\section{Results}

Studies carried out for a fully warmed-up engine operating at a speed of $1000 \mathrm{rpm}$ and at $2500 \mathrm{rpm}$ indicate a beneficial effect of carbon nanotubes on losses due to friction in the engine. For engine speed equal to $2500 \mathrm{rpm}$ an average torque of $47.17 \mathrm{~N} \cdot \mathrm{m}$ was obtained using oil without carbon nanotubes and $45.19 \mathrm{~N} \cdot \mathrm{m}$ for oil with added carbon nanotubes. Reduction of the external drive torque resulting from the application of carbon nanotubes is therefore about $4.2 \%$. At the speed of $1000 \mathrm{rpm}$, the difference increased to $7.1 \%$, and the absolute values of the external drive torque for regular oil and nanotube oil were $36.57 \mathrm{~N} \cdot \mathrm{m}$ and $33.96 \mathrm{~N} \cdot \mathrm{m}$ respectively. Each measurement was repeated three times, and the dispersion of resulting measurements averaged 0.2 $\mathrm{N} \cdot \mathrm{m}$ up to a maximum less than $0.6 \mathrm{~N} \cdot \mathrm{m}$.

\section{Analysis}

The results indicate a significant potential to reduce losses due to friction in piston engines as a result of the addition of nanotubes to the lubricating oil. It should be strongly emphasized, however, that the review of the literature and the results of preliminary engine tests are a justification to undertake further detailed studies. The results are not sufficient to postulate the implementation of relevant industrial applications of carbon nanotubes; a number of problems listed below still require explanation:

- Nanotubes do not form a suspension of sufficient dispersion with the engine oil, over time aggregates of up to about $1 \mathrm{~mm}$ are formed. Such particles are easily stopped by the oil filter or settle on the walls of the sump. Figure 7 shows oil droplets affixed to a piece of paper using the oil dipstick immediately after the engine stopped. Figure 8 presents a new oil filter and an oil filter removed after about 2 minutes of work in an engine with oil, which contained the remains of carbon nanotubes.

- It is probable, but not certain, that the desired effects resulting from the use of carbon nanotubes in an external drive are the same for the operating conditions inside the engine. However, the impact of the engine load on the engine losses to friction for oil with the addition of carbon nanotubes remains unknown.

- The effect of nanotubes on the environment and human health has not been explained clearly so far, although a considerable amount of research was done on animals. Due to differences in the protocols of these studies and the dose and exposure time, as well as the use of different animals, the results are contradictory. There are no test results testing the product life cycle; oil recycling methods with the addition of carbon nanotubes are unknown.

\section{Studies of carbon nanotubes used as a layer on the bearing surface of the piston}

A detailed report on the research of carbon nanotubes used in the form of a layer covering the bearing surface of a piston is shown in [15]. Because of the length of this description it will not be repeated in this article. The list below contains only a summary of its achievements: wymontowano, aby uniknąć odfiltrowania nanorurek węglowych tworzących aglomeraty.

- Każdorazowo przed rozpoczęciem badań włączano na około $2 \mathrm{~h}$ układ rejestracji momentu obrotowego i dopiero po tym czasie zerowano momentomierz.

\section{Wyniki badań}

Badania przeprowadzone dla w pełni nagrzanego silnika pracującego z prędkością obrotową równą $1000 \mathrm{obr} / \mathrm{min}$ i $2500 \mathrm{obr} / \mathrm{min}$ wskazują na korzystny wpływ nanorurek węglowych na straty tarcia silnika. Dla prędkości obrotowej $2500 \mathrm{obr} / \mathrm{min}$ uzyskano średni moment obrotowy równy $47,17 \mathrm{~N} \cdot \mathrm{m}$ dla oleju bez nanorurek węglowych oraz 45,19 Nm dla oleju z dodatkiem nanorurek węglowych. Zmniejszenie momentu napędu zewnętrznego wynikające $\mathrm{z}$ zastosowania nanorurek węglowych wynosi tym samym około 4,2\%. Przy prędkości obrotowej 1000 obr/min różnica zwiększyła się do 7,1\%, a bezwzględne wartości momentu napędu zewnętrznego wynosiły odpowiednio $36,57 \mathrm{~N} \cdot \mathrm{m}$ oraz 33,96 N·m. Każdy pomiar powtarzano trzykrotnie, a otrzymany rozrzut wyników pomiarów wynosił średnio 0,2 $\mathrm{N} \cdot \mathrm{m}$, maksymalnie mniej niż $0,6 \mathrm{~N} \cdot \mathrm{m}$.

\section{Interpretacja}

Uzyskane wyniki wskazują na możliwość znacznego zmniejszenia strat tarcia tłokowego silnika spalinowego dzięki zastosowaniu dodatku nanorurek do oleju smarującego. Należy stanowczo podkreślić, że przegląd literatury oraz wyniki wstępnych prób silnikowych stanowią uzasadnienie do podjęcia dalszych, szczegółowych badań. Uzyskane wyniki są niewystarczające do postulowania wdrożenia odpowiedniego zastosowania przemysłowego nanorurek węglowych; wyjaśnienia wymaga wiele zagadnień wymienionych niżej:

- Nanorurki nie tworzą w oleju silnikowym zawiesiny o zadowalającym stopniu dyspersji; $\mathrm{z}$ upływem czasu dochodzi do tworzenia agregatów o wielkości do około $1 \mathrm{~mm}$. Cząstki takie z łatwością są zatrzymywane przez filtr oleju lub osiadają na ściankach miski olejowej. Na rysunku 7 przedstawiono krople oleju naniesione bagnetem kontrolnym na kartkę papieru bezpośrednio po zatrzymaniu silnika. Na rysunku 8 przedstawiono nowy filtr oleju i filtr oleju wymontowany po około 2 minutach pracy w silniku z olejem, w którym znajdowały się pozostałości nanorurek węglowych.

- Jest prawdopodobne, ale nie jest pewne, że korzystne zależności wynikające z zastosowania nanorurek węglowych obserwowane w warunkach napędu zewnętrznego potwierdzą się w warunkach pracy silnika. Nieznany pozostaje jednak wpływ obciążenia silnika na straty tarcia silnika $\mathrm{z}$ olejem $\mathrm{z}$ dodatkiem nanorurek węglowych.

- Do tej pory nie wyjaśniono jednoznacznie wpływu nanorurek na środowisko i zdrowie człowieka, choć przeprowadzono wiele badań na zwierzętach. Ze względu na różnice w protokołach tych badań, wykorzystanie różnych zwierząt, dawek i czasu ekspozycji otrzymane wyniki są wzajemnie sprzeczne. Nie ma wyników badań cyklu 
1. A prototype piston with a carbon nanotube covered side-surface operating in contact with the cylinder was produced. A technique allowing for application of layers of nanotubes onto surfaces on industrial scale was developed.

2. Due to the limited resistance of aluminum alloys at high temperatures it is difficult to use the established method of chemical synthesis of carbon nanotubes CVD, which typically leads to good results, on the bearing surface of standard pistons. This limitation does not apply to steel pistons, which may be more widely used in the future due to multiple reasons. Experimental pistons were made of standard aluminum alloy and coated with a layer of nanotubes deposited via spraying an aqueous solution containing a carbon nanotubes mixed with a chemical binder.

3. The technique used for the application of carbon nanotubes is very similar to offset printing method, utilized for the application of standard graphite layers to the bearing surfaces of the pistons manufactured industrially. It is easy to implement this technique into mass production of pistons as it was used to produce the experimental pistons.

4. Images of the samples taken from the surface of the pistons after engine tests, recorded using a transmission electron microscope TEM, confirm the resistance of carbon nanotubes to the chemical environment and mechanical loads occurring on the bearing surface of engine pistons.

5. Measurements of surface roughness as well as the deviations of shapes of the pistons made before and after tests

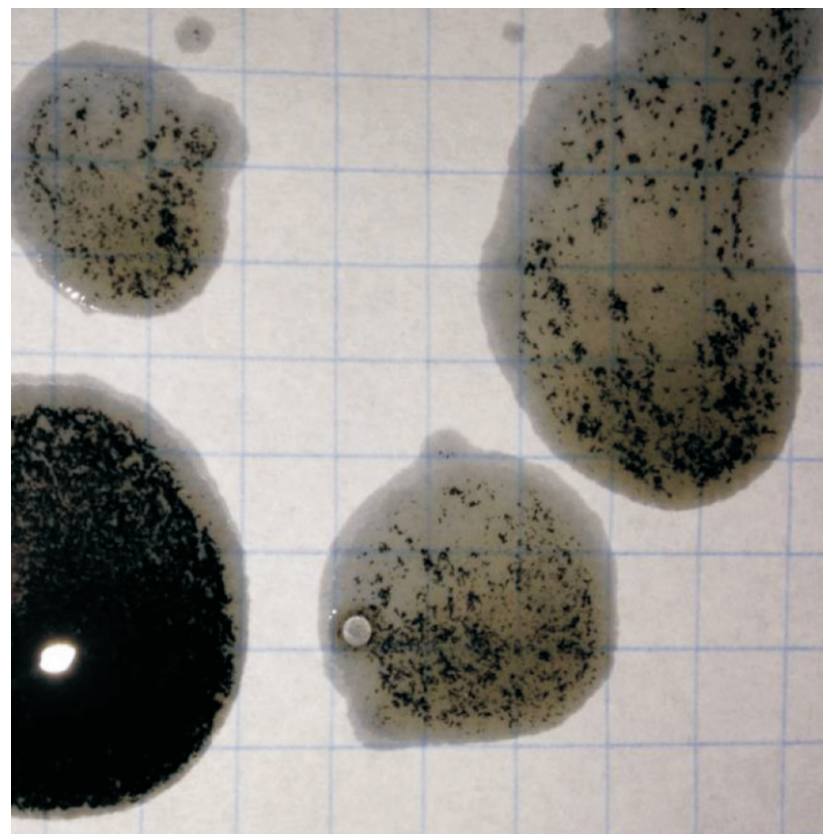

Fig. 7. Droplets of oil with the addition of carbon nanotubes deposited on piece of paper with the oil dipstick, visible agglomerates formed by the nanotubes

Rys. 7. Krople oleju z dodatkiem nanorurek węglowych naniesione bagnetem kontrolnym na kartke papieru; widoczne aglomeraty utworzone przez nanorurki życia produktu; nieznane są metody recyklingu oleju $\mathrm{z}$ dodatkiem nanorurek węglowych

\section{Badania nanorurek węglowych zastosowanych jako warstwa na powierzchni nośnej tloka}

Szczegółowy raport z badań nanorurek węglowych zastosowanych między innymi w formie warstwy pokrywającej powierzchnię nośną tłoka silnika przedstawiono w pracy [15]. Ze względu na obszerność, opis ten nie będzie powtórzony w niniejszym artykule; poniżej zamieszczono jedynie streszczenie osiągnięć.

1. Wykonano prototypowy tłok, którego powierzchnia boczna w części współpracującej z cylindrem pokryta została nanorurkami węglowymi. Opracowano technologię nanoszenia warstw nanorurek możliwą do zastosowania w przemysłowej skali produkcji.

2. Ze względu na ograniczoną odporność stopów aluminium na wysoką temperaturę utrudnione jest wykorzystanie sprawdzonej, prowadzącej do dobrych rezultatów chemicznej metody syntezy nanorurek węglowych CVD na powierzchni nośnej standardowych tłoków. Ograniczenie to nie dotyczy tłoków stalowych, które w przyszłości mogą być $\mathrm{z}$ wielu innych powodów szerzej stosowane. Tłoki eksperymentalne wykonano ze standardowego stopu aluminium i pokryto warstwą nanorurek naniesionych metodą natryskową w roztworze wodnym $\mathrm{z}$ dodatkiem spoiwa.

3. Zastosowana technologia nanoszenia nanorurek węglowych jest bardzo podobna do metody sitodruku, stosowanej w celu nanoszenia standardowych warstw grafitowych na powierzchnie nośne tłoków produkowanych seryjnie. Bardzo łatwo można wdrożyć produkcję wielkoseryjną z wykorzystaniem technologii zastosowanej do wykonania tłoków eksperymentalnych.

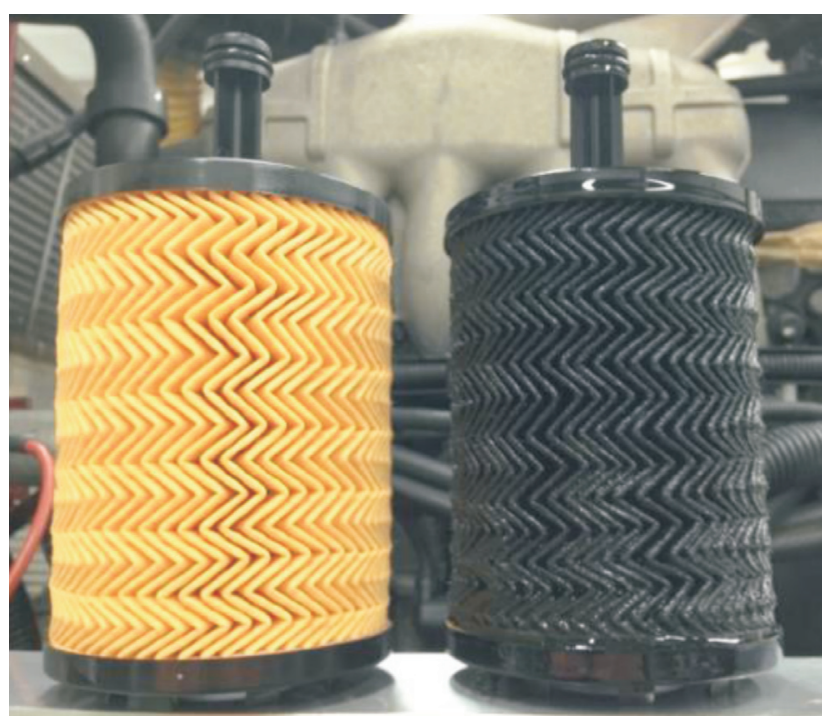

Fig. 8. New oil filter (left) and a filter removed after two minutes operation in the engine oil which contained a residue of carbon nanotubes (right)

Rys. 8. Filtr oleju nowy (z lewej strony) i wymontowany po dwóch minutach pracy $w$ silniku z olejem, $w$ którym znajdowaty się pozostałości nanorurek węglowych 
showed high abrasion of layers of carbon nanotubes. However, this problem arises primarily from the type of binder used, and not the properties of the carbon nanotubes themselves and it is likely it can be easily solved in the future.

6. The results of a substantial part of the research indicate that following the application of experimental pistons in the test engine the total moment of the external drive mounted in the experimental setup decreased in the vast majority of operating points, as determined by the speed, oil temperature and pressure in the cylinder. The difference in the measured external drive torque of standard pistons and prototype pistons - coated with a layer of nanotubes - amounted to $16 \%$.

7. The experimental pistons removed from the engine after the tests completed were not significantly different in outer diameter or surface roughness to the reference pistons. Hence the criterion for the comparability of friction losses was met.

8. It has been shown that carbon nanotubes do not adversely affect the process of cylinder liner wear.

At the same time the research work presented above helped identify a number of questions and technological problems, the solution of which may be the subject of further research.

- A study of the effects of addition of carbon nanotubes to the engine oil on the working conditions of nodes of friction.

- Determining the impact of carbon nanotube layer covering the bearing surfaces of the piston on its lateral movement and vibration damping.

- Studying the impact of the type of carbon nanotubes, the characteristics of their design and the layer structure on friction losses in real working conditions present in friction nodes of piston internal combustion engine. The production of experimental pins and piston rings, elements of plain bearings of crankshaft and timing system components with sliding surfaces coated with layers of carbon nanotubes as well as the analysis of the impact of these layers on engine working conditions.

- Determining the impact of the method of incorporating a layer of carbon nanotubes on the functional properties of coatings applied to the sliding surfaces. Using the method of chemical synthesis of nanotube layers CVD to form carbon nanotubes on elements resistant to high temperature.

- Development of improved binders for nanotubes applied by spraying or screen printing, the applicability of resins used in applying layers of graphite to the bearing surface of a piston. Increasing the abrasion resistance of layers of nanotubes.

- Examining the impact of a nanotube layer of relatively high abrasion to prevent seizing of a new engine in a maximum engine load test in a cold start. Such a test is particularly important to ensure proper operation of supercharged engines with high unit power in extreme conditions.
4. Obrazy próbek powierzchni tłoków pobranych po badaniach silnikowych, zarejestrowane z użyciem elektronowego mikroskopu transmisyjnego TEM, stanowią potwierdzenie odporności nanorurek węglowych na środowisko chemiczne i obciążenia mechaniczne występujące na powierzchni nośnej tłoków.

5. Na podstawie pomiarów chropowatości i odchyłek kształtu tłoków, wykonanych przed rozpoczęciem i po zakończeniu badań, wykazano dużą ścieralność warstw nanorurek węglowych. Problem ten wynika jednak przede wszystkim z rodzaju zastosowanego spoiwa, a nie z właściwości nanorurek węglowych i prawdopodobnie może być w przyszłości łatwo rozwiązany.

6. Wyniki zasadniczej części badań świadczą o tym, że w następstwie zastosowania tłoków eksperymentalnych całkowity moment napędu zewnętrznego silnika zamontowanego na stanowisku symulacyjnym zmalał w znacznej większości punktów pracy, opisanych prędkością obrotową, temperaturą oleju i ciśnieniem w cylindrze. Różnica momentu napędu zewnętrznego zmierzona dla silnika z tłokami standardowymi i prototypowymi - pokrytymi warstwą nanorurek - wynosiła do $16 \%$.

7. Wymontowane z silnika tłoki eksperymentalne nie różniły się znacznie średnicą zewnętrzną ani chropowatością powierzchni od tłoków referencyjnych; tym samym zostało spełnione podstawowe kryterium porównywalności strat tarcia.

8. Wykazano, że nanorurki węglowe nie wpływają negatywnie na proces zużycia tulei cylindrowej.

Jednocześnie wykonanie przedstawionej wyżej pracy badawczej pozwoliło wskazać wiele pytań badawczych i problemów technologicznych, których rozwiązanie może być przedmiotem dalszych prac:

- Badanie wpływu dodatku nanorurek węglowych do oleju silnikowego na warunki pracy węzłów tarcia.

- Określenie wpływu warstwy nanorurek węglowych pokrywającej powierzchnie nośne tłoka na jego ruchy poprzeczne i tłumienie drgań.

- Badanie wpływu rodzaju nanorurek węglowych, cech ich budowy i struktury warstwy na straty tarcia w rzeczywistych warunkach panujących w węzłach tarcia tłokowego silnika spalinowego. Wykonanie eksperymentalnych sworzni i pierścieni tłokowych, elementów łożysk ślizgowych wału korbowego i elementów układu rozrządu z powierzchniami ślizgowymi pokrytymi warstwami nanorurek węglowych i analiza wpływu tych warstw na warunki pracy.

- Określenie wpływu metody konstytuowania warstwy nanorurek węglowych na jej cechy funkcjonalne w zastosowaniu do pokrycia powierzchni ślizgowych. Wykorzystanie metody chemicznej syntezy nanorurek CVD do wytworzenia warstw nanorurek węglowych na elementach odpornych na wysoką temperaturę.

- Opracowanie udoskonalonych spoiw dla nanorurek nanoszonych natryskowo lub metodą sitodruku, wykorzystanie żywic stosowanych w warstwach grafitowych nanoszonych na powierzchnię nośną tłoka. Zwiększenie odporności ściernej warstw nanorurek. 
- Development and testing of covers for sliding surfaces in which the nanotubes make up a substrate for attaching nanoparticles with favorable tribological properties, such as molybdenum disulfide.

- Analysis of the results of the proposed research and development of multi-layered sliding surfaces, including the bearing surface of the piston. Individual coating layers, starting from the surface of the base material of the piston, should be constructed to perform specialized functions:

- damping forces resulting from the piston hitting the wall of the cylinder by elastic deformation; it has been demonstrated that nanotubes with ordered growth direction exhibit particularly advantageous properties in this regard [11],

- reducing losses due to friction and possibly creating a base for application of anti-abrasion nanoparticles,

- protective wear layer for the process of engine breakin.

\section{Conclusions}

The obtained results show that it is appropriate to undertake research and development towards the use of carbon nanotubes in engine design. Favorable tribological properties of carbon nanotubes have been shown, allowing the reduction of friction and improvement of the mechanical efficiency of the engine. Previous works are characterized by their interdisciplinary nature and required a combination of knowledge in the fields of construction and operation of internal combustion engines as well as chemistry, physics, and materials science. In further works aimed at industrial applications of carbon nanotubes it will be necessary to examine the life cycle of the product, its impact on humans and the environment and to develop recycling methods.
- Zbadanie wpływu warstwy nanorurek o dużej ścieralności na zapobieganie zatarciu nowego silnika w teście maksymalnego obciążenia silnika nierozgrzanego. Test taki ma szczególne znaczenie dla zapewnienia właściwej pracy doładowanych silników o dużych mocach jednostkowych w skrajnych warunkach eksploatacji.

- Opracowanie i zbadanie pokryć powierzchni ślizgowych, w których nanorurki stanowią podłoże do osadzenia nanocząstek o ustalonych korzystnych właściwościach tribologicznych, takich jak np. dwusiarczek molibdenu.

- Analiza wyników proponowanych badań i opracowanie wielowarstwowych pokryć powierzchni ślizgowych, między innymi powierzchni nośnej tłoka. Poszczególne warstwy powłoki w kolejności od powierzchni materiału rodzimego tłoka powinny być tak zbudowane, by pełnić wyspecjalizowane funkcje:

- tłumienia sił wynikających z uderzania tłoka w ściankę cylindra przez deformację sprężystą; dowiedziono, że szczególnie korzystne cechy wykazują w tym zakresie nanorurki o uporządkowanym kierunku wzrostu [11],

- ograniczania strat tarcia i ewentualnie podłoża dla nanocząstek stanowiących dodatki przeciwcierne,

- warstwy ścieralnej zabezpieczającej silnik na etapie docierania.

\section{Podsumowanie}

Uzyskane wyniki badań wskazują, że celowe jest podjęcie prac badawczo-rozwojowych odnośnie do zastosowania nanorurek węglowych w konstrukcji silnika. Dowiedziono korzystnych właściwości tribologicznych nanorurek węglowych, powalających na zmniejszenie tarcia i poprawę sprawności mechanicznej silnika. Dotychczasowe prace cechują się interdyscyplinarnym charakterem $i$ wymagały połączenia wiedzy z zakresu budowy i działania tłokowych silników spalinowych oraz chemii, fizyki i materiałoznawstwa. $\mathrm{W}$ pracach mających na celu zastosowania przemysłowe dodatkowo konieczne będzie zbadanie cyklu życia produktu, jego wpływu na człowieka i środowisko oraz opracowanie metod recyklingu.

\section{Bibliography/Literatura}

[1] Abad M.D., Sánchez-López J.C., Berenguer-Murcia A., Golovko V.B., Cantoro M., Wheatley A.E.H., Fernández A., Johnson B.F.G., Robertson J. Catalytic growth of carbon nanotubes on stainless steel: characterization and frictional properties. Diamond and Related Materials, 11 (17), 2008.

[2] Adam A., Prefot M., Wilhelm M. Kurbelwellenlager für Motoren mit Start-Stop-System. MTZ, 12, 2010.

[3] Atsushi H., Nobuaki Y. Sliding friction properties of carbon nanotube coatings deposited by microwave plasma chemical vapor deposition. Tribology International, 11-12 (37), 2004.

[4] Baughman R.H., Zakhidov A.A., de Heer W.A. Carbon nanotubes - the route toward applications. Science, 5582 (297), 2002, 787-792.

[5] Bhushan B. Springer Handbook of Nanotechnology, third edition, revised and expanded, Springer Verlag, Berlin-Heidelberg 2010.
[6] Brand L., Gierlings M., Hoffknecht A., Wagner V., Zweck A. Kohlestoff-Nanorörchen: Potenziale einer neuen Materialklasse für Deutschland. Technologieanalyse, VDI Technologiezentrum $\mathrm{GmbH}$, Düsseldorf 2009.

[7] Chauveau V., Mazuyer D., Dassenoy F., Cayer-Barrioz J. In situ film-forming and friction-reduction mechanisms for carbon-nanotube dispersions in lubrication. Tribology Letters, 3 (47), 2012, 467-480.

[8] Cook E.H., Buehler M.J., Spakovszky Z.S. Mechanism of friction in rotating carbon nanotube bearings. Journal of the Mechanics and Physics of Solids, 61, 2013, 652-673.

[9] Cursaru D.L., Andronescu C., Pirvu C., Ripeanu R. The efficiency of Co-based single -wall carbon nanotubes (SWNTs) as an AW/EP additive for mineral base oils. Wear, 290-291, 2012, 133-139. 
[10] Dekker C. Carbon nanotubes as molecular quantum wires. Physics Today, 5, 1999.

[11] Fenimore A.M., Yuzvinsky T.D., Han W.Q., Fuhrer M.S., Cumings J., Zettl A. Rotational actuators based on carbon nanotubes, Nature, 424 (6947), 2003, 408-410.

[12] Harris P.J.F. Carbon nanotubes and related structures. Cambridge University Press, Cambridge 1999.

[13] Huang J.Y., Chen S., Wang Z.Q., Kempa K., Wang Y.M., Jo S.H., Chen G. Dresselhaus M.S., Ren Z.F. Superplastic carbon nanotubes. Nature, 439, 281, 2006.

[14] Johanne L.B., Yowell L.L., Sosa E., Arepalli S., Mishra R.S. Survivability of single-walled carbon nanotubes during friction stir processing. Nanotechnology, 17, 3081, 2006.

[15] Kałużny J. Eksperymentalne zastosowania nanorurek węglowych w konstrukcji tłokowego silnika spalinowego. Wydawnictwo Politechniki Poznańskiej, Poznań 2013.

[16] Kashyap K.T., Rahul R., Yamdagni S. Strengthening in carbon nanotube/aluminium (CNT/Al) composites. Scripta Materialia, 10 (53), 2005, 1159-1163.

[17] Kogovšek J., Remškar M., Mrzel A., Kalin M. Influence of surface roughness and running-in on the lubrication of steel surfaces with oil containing MoS2 nanotubes in all lubrication regimes. Tribology, 61, 2013, 40-47.

[18] Kotnarowski A. Konstytuowanie warstw ochronnych z nanoproszków miedzi i molibdenu w procesach tribologicznych, Wydawnictwo Politechniki Radomskiej, Radom 2009.

[19] Lin R.M., Lu C. Modeling of interfacial friction damping of carbon nanotube-based nanocomposites. Mechanical Systems and Signal Processing, 8 (24), 2010.

[20] Lu H., Goldmann J., Ding F., Sun Y., Pulikka-thara M.X., Khabashesku V.N., Yakobson B.I., Lou J. Friction and adhesion properties of vertically aligned multi-walled carbon nano-tube arrays and fluoro-nanodiamond films. Carbon, 10 (46), 2008, 1294-1301.

[21] Lucas M., Palaci I., Riedo E., Zhang X., To-satti E. Hindered rolling and friction anisotropy in supported carbon nanotubes. Nature Materials, 8, 2009, 876-881.

[22] Meng H., Sui G.X., Xie G.Y., Yang R. Friction and wear behavior of carbon nanotubes reinforced polyamide 6 composites under sliding and water lubricated condition. Composites Science and Technology, 5 (69), 2009, 606-611.

[23] Méténier K., Bonnamy S., Béguin F., Journet C., Bernier P., de la Chapelle L.M., Chauvet O., Lefrant S. Coalescence of single walled nanotubes and formation of multi-walled carbon nanotubes under high temperature treatments. Carbon, 40, 2002, 1765-1773.

[24] Pottuz L.J., Dassenoy F., Vacher B., Martin J.M., Mieno T. Ultralow friction and wear behavior of $\mathrm{Ni} / \mathrm{Y}$-based single wall carbon nano-tubes (SWNTs). Tribology International, 11-12 (37), 2004.

[25] Qianming G., Dan L., Xiaosu Y., Ji L. Tribology of polymeric nanocomposites. Friction and Wear of Bulk Materials and Coatings, Elsevier 2013.

[26] Saito Y. Nanoparticles and filled nanocapsules. Carbon, 7 (33), 1995, 979-988.

[27] Salvetat J.P., Bonard J.M., Thomson N.H., Kulik A.J., Forró L., Benoit W., Zuppiroli L. Mechanical properties of carbon nanotubes. Applied Physics A, 69,1999, 255-260.

[28] Servantir J., Gaspard P. Rotational dynamics and friction in double-walled carbon nanotubes, Phys. Rev. Lett, 97 (18), 2006.

[29] Tehrani M., Safdari M., Boroujeni A.Y., Razavi Z., Case S.W., Dahmen K., Garmestani H., Al-Haik M.S. Hybrid carbon fiber/ carbon nanotube composites for structural damping applications. Nanotechnology, 24, 155704, 2013.

[30] Tersoff J., Ruoff R.S. Structural properties of a carbon-nanotube crystal. Physical Review, 5 (73), 1994, 676-679.

[31] Treacy M.M.J., Ebbesen T.W., Gibson J.M. Exceptionally high Young's modulus observed for individual carbon nanotubes. Nature, 381, 1996, 678-680.

[32] De Volder M.F.L., Tawfick S.H., Baughman R.H., Hart A.J. Carbon nanotubes: present and future commercial applications. Science, 6119 (339), 2013, 535-539.

[33] Vander Wall R.L., Miyoshi K., Street K.W., Tomasek A.J., Peng H., Liu Y., Margrave V.N., Khabashesku V.N. Friction properties of surface-fluorinated carbon nanotubes. Wear, 1-6 (259), 2005, 738-743.

[34] Wang N., Tang Z.K., Li G.D., Chen J.S. Single-walled $4 \AA$ carbon nanotube arrays. Nature, 408, 2000, 50-51.

[35] Yao N., Lordie V. Young's modulus of single-wall carbon nanotubes. Journal of Applied Physics., 84, 1998, 1939-1943.

[36] Zhang S., Liu W.K., Ruoff R.S. Atomistic simulations of double-walled carbon nanotubes (DWCNTs) as rotational bearings. Nano Letters, 4 (2), 2004.

[37] Hountalas D.T., Kouremenos A.D. Development of fast and simple simulation model for the fuel injection system of diesel engines. Advanced in Engineering Software, 1 (26), 1998, $13-28$.
Jarosław Kałużny, DSc., DEng. - Faculty of Architecture at Poznan University of Technology.

Dr hab. inż. Jarosław Kahużny - Wydziat Architektury Politechniki Poznańskiej.

e-mail: jaroslaw.kaluzny@put.poznan.pl

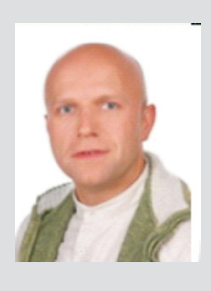

Prof. Krzysztof Kempa, DSc. - Department of Physics, Boston College, USA.

Prof. dr hab. Krzysztof Kempa - Wydziat Fizyki, Boston College, USA.

e-mail: kempa@bc.edu

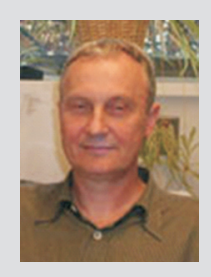

Prof. Antoni Iskra DSc., DEng. - Faculty of Machines and Transport at Poznan University of Technology.

Prof. dr hab. inż. Antoni Iskra-Wydzial Maszyn Roboczych i Transportu Politechniki Poznańskiej. e-mail: antoni.iskra@put.poznan.pl

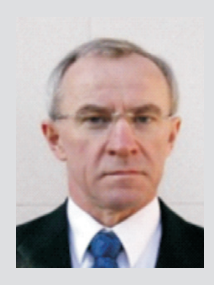

Prof. Michael Giersig, DSc. - Department of Physics, Freie University Berlin, Germany.

Prof. dr hab. Michael Giersig - Wydzial Fizyki, Freie Universität Berlin, Niemcy.

e-mail: giersig@physik.fu-berlin.de

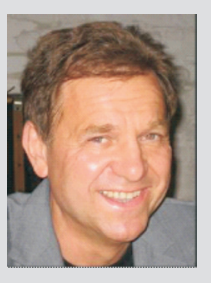

